IIUC STUDIES

ISSN 1813-7733

Vol.- 7, December 2010

(Published in December 2011) (p 37-48)

\title{
Mobile Commerce and Mobile Payment: A Study on Islamic Perspective
}

\author{
Md. Monirul Islam*
}

Abdul Kadar Muhammad Masum ${ }^{* *}$

\begin{abstract}
Electronic commerce, very important part of Information and Communication Technologies (ICT), is one of the most common business terms in use in 21st century. Developed countries are more popular because of their rapid growth of ICT, e-commerce and online transaction. But in developing or under develop countries the scenario is different. Technical laggings, dearth of infrastructure, infeasibility of the existing frameworks and people apathy are the main reasons behind this. There are several alternative ways of e-commerce and online transaction. Mobile payment, a way of online transaction, may be beneficial way of payment for developing countries because of its mobile network infrastructure. In this paper, a model of electronic payment system for M-Commerce has been proposed and analyzed the security for the system. This proposal may be suitable for developing countries where mobile phones are available but other e-payment tools like debit and credit cards are not much available. It also identifies what Islam has to say about our current use of M-Commerce and the way Islam can offer guidance for its use in the future. The paper also touches on the conditions and criteria that must be met in order to make an M-Commerce transaction acceptable under Islamic perspective.
\end{abstract}

Keywords: B2C: Business to Customer, M-Commerce: Mobile Commerce, M-Payment: Mobile Payment, SMS: Short Message Service, Islamic perspective

\section{INTRODUCTION}

Electronic commerce is a general term for any type of business, or commercial transaction, which involves the transfer of information

* Assistant Professor, Department of Computer Science \& Engineering (CSE), IIUC.

** Assistant Professor, Dept. of Business Administration, IIUC (Dhaka Campus). 
across the Internet [1]. M-Commerce, a part of E-Commerce, is offering much more to users to conduct business. In this paper, an infrastructure model of secured M-Payment is proposed integrating mcommerce through SMS and e-commerce. In a model, the overall security of M-Commerce is analyzed where large amount of transaction will be suitable. The Islamic view point has been presented about M-Commerce, E-Payment, E-Commerce and SMS.

\section{BACKGROUND STUDY}

\section{A. TRADITIONAL PAYMENT SYSTEM}

Mobile commerce addresses electronic commerce via mobile devices including mobile phones, PDAs, wireless tablets, and mobile computers and has brought to realize the potential of the Internet to dramatically reduce cost and raise efficiency, across the supply chain. In a traditional business system, the payment system for every stage of selling goods or providing services is physically done by the exchange of notes and coins to issuing cheques. [2] These processes are too much risky and make our lives scared. There are also Credit card and Debit card systems for online transactions, which are not very much suitable for its scarcity of booth.

\section{B. WHY MOBILE COMMERCE}

For communication purpose email and messaging have become part and parcel of our daily lives. [3] Most of the people of Bangladesh have lacking in Internet skills, access to a PC and it is due to lack of sufficient Internet facilities. Mobile on the other hand has become prominent to every level of people. [4] Mobile costs have become cheaper. Even in the rural areas the coverage has been made available. People are accepting mobile as their communication device as transfer of information is most necessary for livelihood. In case of younger customers SMS has turned out to be most accepted tool for communication. [5]

The table below indicates the use of M-commerce globally.

Table 1: Global Mobile Commerce Revenues [6]

\begin{tabular}{|c|c|}
\hline Year & US \$ Billions (2004-2008) \\
\hline 2004 & 10 \\
\hline 2005 & 18 \\
\hline 2006 & 24 \\
\hline 2007 & 36 \\
\hline 2008 & 55 \\
\hline
\end{tabular}


Table 2: Total SMS Revenues Worldwide - 2007-14 [7]

\begin{tabular}{|c|c|}
\hline Year & Approximate SMS Revenue (\$ Billion) \\
\hline 2007 & 55 \\
\hline 2008 & 75 \\
\hline 2009 & 150 \\
\hline By 2014 & 233 (expected) $[14]$ \\
\hline
\end{tabular}

\section{BASIC CATEGORY OF M-PAYMENT}

Mobile payments can be divided into macro and micro payments:

- A micro-payment refers to a payment of approximately $\$ 10$ or less, and in the mobile environment this will often be for video downloads or gaming.

- Macro-payments refer to larger value payments such as online shopping or proximity-based payments.

For every macro-payment transaction through a trusted financial entity is extremely important, whereas network authentication, such as SIM, may be sufficient for micro-payments that only use the operator's infrastructure. [2]

\section{PROBLEMS FACED BY M-PAYMENT}

There are three main requirements for the adoption of mobile payments that are being addressed by the researchers. These are:

Security: Sufficient security minimizes fraud. There are four main security elements that need to be addressed:

- Authentication allows the payment provider (that is, the issuer) to determine that the person using the payment product is the authorized user.

- As the matter is confidential, unauthorized parties do not have access to sensitive payment.

- Integrity of data ensures no alteration of the terms of transaction.

Usability: Research has shown that consumers are attracted to products that are simple to use and do not require major shifts in habit. Any mobile payment system must fulfill these requirements. [3]

\section{METHODOLOGY}

The M-Commerce market has grown significantly over the past few years. This study of M-commerce and M-payment is based on 
secondary data. Besides that a model of electronic payment system for M-Commerce has been proposed and analyzed the security for the system. The Islamic perspective of M-commerce and M-payment also has been discussed based on the Holly Qur'an and Hadith of the Prophet Muhammad (SAW).

\section{PROPOSED M-PAYMENT SYSTEM}

\section{A. PROPOSED ALGORITHM FOR SECURED SMS}

Before transmitting the SMS, it will be encrypted and decrypted after receiving.

\section{A.1 PROPOSED ENCRYPTION ALGORITHM}

1. Choose random number, $k$ in the range of 1 and 3 .

2. Multiply the ASCII value of the character with $3^{k}$ that gives a number, $M U L$. Check the digit of the $k^{\text {th }}$ position in the number. If it is 9 than hide the digit and make the number negative for exception handling because hidden digit 9 and 0 make the same result which makes confusion. Otherwise just hide the $k^{\text {th }}$ digit only from the number. Let the number is $M$.

3. Put $k$ in front of the number that produces, ENC.

\section{A.2 PROPOSED DECRYPTION ALGORITHM}

1. Get $E N C$ and First of all take first digit, $k$ from received number which gives $M$ and that consists of rest of the digits without $k^{\text {th }}$ position.

2. See that whether $M$ is negative or not. If negative than put 9 at $k^{\text {th }}$ position and make the number positive. Otherwise make summation of all digits, $S$ of the number.

3. Set $L=9$ and continue the operation $L=L+9$ until $L>S$. subtract $S$ from $L$ and get the hidden digit in the number. Put the digit at $k^{\text {th }}$ position and get the complete number, $M U L$.

4. Now divide $M U L$ with $2^{k}$ and get the ASCII value of the original character.

Example 1:

Encryption

1. ASCII value of $\mathrm{a}=97$, if $\mathrm{k}=2$ than $\mathrm{MUL}=97 * 3^{2}=873$

2. Hiding $\mathrm{k}^{\text {th }}$ position, $\mathrm{M}=83$

3. $\mathrm{ENC}=283$ 
Decryption

1. $\mathrm{ENC}=283$

2. $\mathrm{k}=2, \mathrm{~S}=11$

3. $\mathrm{L}=9,18>\mathrm{S}$ after continuing the loop of statement $\mathrm{L}=\mathrm{L}+9$. Now $18-11=7$. Putting 7 in $2^{\text {nd }}$ position, $\mathrm{MUL}=873$

4. $\mathrm{MUL} / 3^{2}=97$. So $97=\mathrm{ASCII}$ value of a.

\section{Example 2:}

Encryption

1. ASCII value of $\mathrm{o}=111$, if $\mathrm{k}=3$ than $\mathrm{MUL}=111^{*} 3^{3}=2997$

2. Hiding $\mathrm{k}^{\text {th }}$ position, $\mathrm{M}=297$

3. $\mathrm{ENC}=-3297$

\section{Decryption}

1. $\mathrm{ENC}=-3297$

2. $\mathrm{ENC}<0$, So $\mathrm{MUL}=2997$

3. $\mathrm{MUL} / 3^{3}=111.111=\mathrm{ASCII}$ value of $\mathrm{o}$.

\section{Example 3:}

Encryption

1. ASCII value of $\mathrm{r}=114$, if $\mathrm{k}=2$ than $\mathrm{MUL}=114 * 3^{2}=1026$

2. Hiding $\mathrm{k}^{\text {th }}$ position, $\mathrm{M}=126$

3. $\mathrm{ENC}=2126$

\section{Decryption}

1. $\mathrm{ENC}=2126$

2. $\mathrm{k}=2, \mathrm{~S}=9$

3. $\mathrm{L}=9,9>\mathrm{S}$. Now $9-9=0$. Putting 0 in $2^{\text {nd }}$ position, $\mathrm{MUL}=1026$

4. $\mathrm{MUL} / 3^{2}=114$. So $114=\mathrm{ASCII}$ value of $\mathrm{r}$.

Here complexity is $\mathrm{O}(\mathrm{n})$.

\section{B. PROPOSED ARCHITECTURE}

2. Customer SMS transmitter and receiver

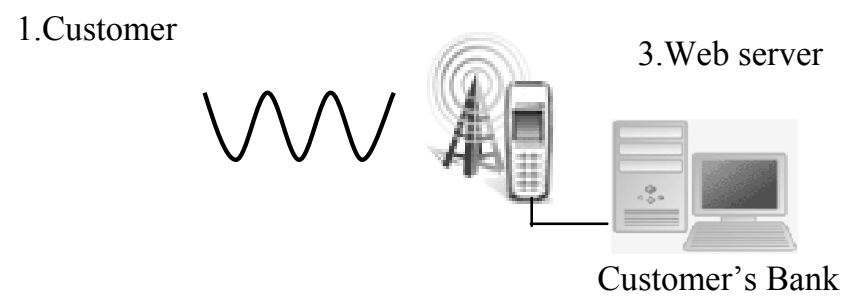




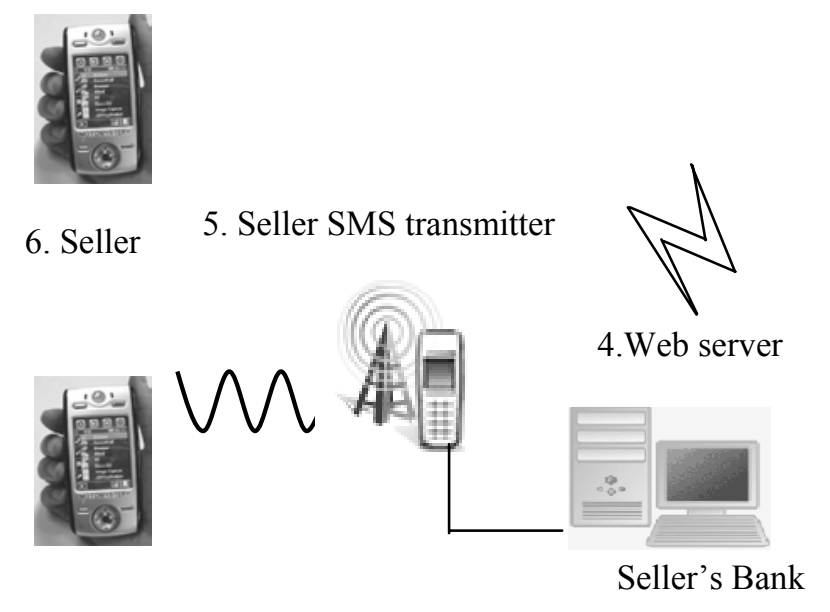

Fig. 1 proposed logical connection for payment between customer and seller using cell phone and Internet.

The proposed system consists of two different technologies, which are cell phone and Internet technology. Fig.1 shows the logical payment connection between customer and seller for transaction. A web server with live IP address on an interface must be configured with Secured Socket Layer (SSL) technology in both customer's and seller's bank side for security of account and acknowledgement information exchange over Internet.

There are only three steps to complete a transaction between customer and seller using proposed method that is reflected in Fig.2. The steps are as follows.

Step 1: Customer sends encrypted SMS (short message service) from cell phone to his bank's specific cell number by informing his ID, password, seller account, deposit amount and other necessary information. Interfacing supportive software can process the message, which is in PDU or text format.

Step 2: Cell phone at customer's bank receives message and decrypts the SMS and passes that to associated computer for authentication. If customer ID, password, account id, account constraints etc are valid than it passes some arguments including seller's account ID, amount to be paid, etc using Internet. 


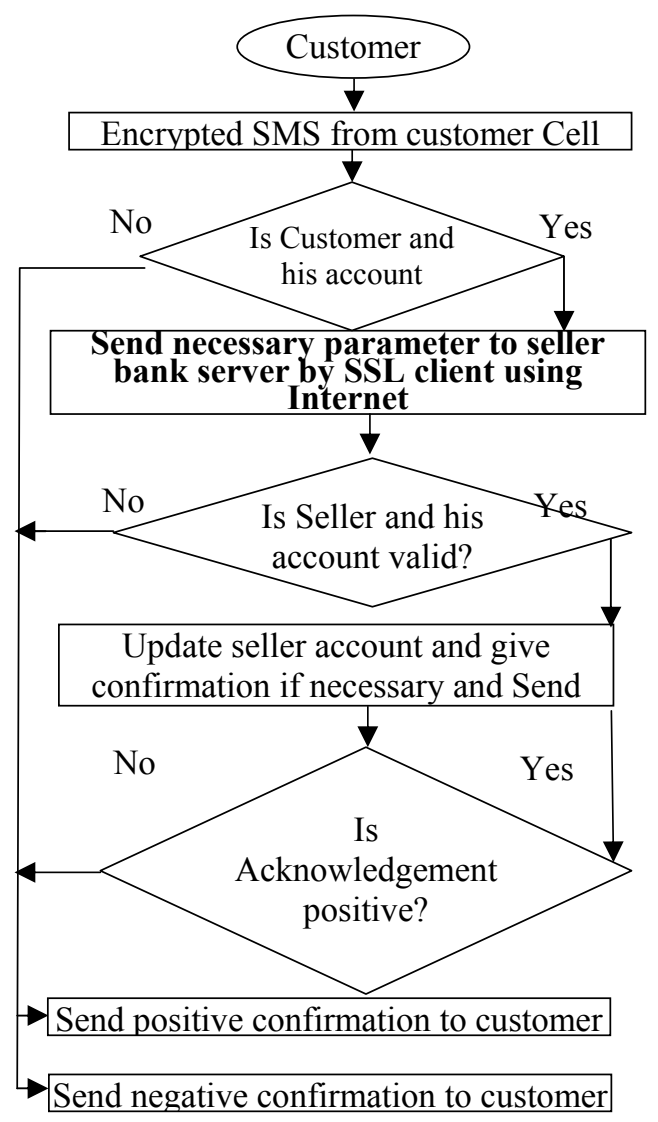

Fig.: 2 Steps to Complete Transaction between Customer and Seller.

Step 3: On the basis of validity of seller's account seller's bank updates seller account and confirms the seller about the update if necessary and sends acknowledgement to customer's bank. If the acknowledgement is positive than customer bank updates customer account and sends positive confirmation.

\section{BENEFITS OF THE PROPOSED MODEL}

Our proposed M-payment model overcomes the problem of Third Part and its functionality is convenient than the third party and the overall operation of the system is very much simple and easy to implement. Several advantages are: 
1. Any kind of transaction is possible: Mobile payment is suitable for micro-payment as in macro payment a high-secured network is required. Our proposed system is secure for macro-payment. Here we are using Secured Socket Layer (SSL) along with mobile network.

2. No extra charge without SMS charge: There is no monthly statement for charge or any kind of hidden bill for every transaction without SMS charge.

3. Easy to access: In our proposed model a buyer only sends a prescribed format of SMS. The program of the mobile set will encrypt the SMS.

\section{A. THE REASON BEHIND CHOOSING SMS APPLICATION}

SMS application is available in most GSM mobile sets. In Bangladesh we use GSM mobile sets only. The number of GSM subscribers has grown from 1 million in 1990 to 787.5 million in 2002. SMS has become the most popular way to communicate for the age group of 18-35 year. [3] On average one billion SMS messages are sent per day. One of the researchers produces the following basic criterions in support of SMS:

It is instant (you immediately get updated when an SMS arrives). It's private and easy. It always works.

It gives the person receiving SMS psychological importance as if the message was sent in a one to one basis, even though it might have been sent in a group. WAP service is also not easily available all over Bangladesh and also in most mobile sets. [7] Cheaper than other application as it would cost a user 4-7Tk per minute to make call while one SMS would cost no more than 2.30Tk. Many mobile service providers (MSP) are providing a certain number of SMS on free of cost. [9]

\section{ISLAMIC PERSPECTIVE OF M-COMMERCE and M-PAYMENT}

M-commerce, M-payment is a new concept. Then there is no necessity to create new methods to build a modern Islamic Economics. This new concept is suitable in an Islamic Society. [10]

Allah (SWT) said in the Holly Qur'an:

1. "............Allah hath permitted trade and forbidden usury” (2:275)

2. "When you have finished your prayer, then disperse, seeking the grace of God in work and trade”. (62:10) 
3. "There is no harm in trading while ye are engaged in pilgrimage". (2:192)

4. "O man of faith! Do not devour the goods of another with injustice but trade based on mutual agreement and good-will is allowed". (4:29)

5. "O ye who believe; devour not usury, doubled and multiplied; but fear Allah, that ye may prosper" (3:130)

Rafe Ibn Khadiz narrated, when asked to the Prophet (SAW) which income is the best? "He replied who earned by his own hand and by doing the Halal way of trading." (Miskat Sharif)

Imam Malik, on the authority of Abu Sa'id al-Khudri quoted the Prophet (S) as saying "Do not sell gold for gold, except measure for the same measure; and do not sell silver for silver, except measure for the same measure; and do not exchange for future payment in either gold or silver. (Malik, pp58)

From the above verses of the holly qur'an and the ahadith we can confirm that the trade or commerce is allowed but riba or any unjust transaction is haram. So there is nothing wrong in m-commerce or ecommerce if we can avoid the interest or any unjust transaction. The principle of justice was very strictly applied to various forms of exchange in vogue at the time of the holly prophet (saw).

The holly prophet (saw) maintained those forms of transactions which were based on justice and fair play for all and prohibited all those forms of business transactions which were either unjust, or were likely to lead to quarrels and litigation, or resembled gambling, or contained an element of riba or deceit, or where profit of one was based on loss of another. [11]

\section{A. Payment by using Debit Card}

The most common method of e-payments is to use debit card or credit card. Since the debit card is issued against consumer's bank deposits and the money for debit card using purchases is transferred almost immediately from consumer's bank account to the merchant's account so there is no room for interest in using debit card.

\section{B. Payment by using Credit Card}

The credit card is a new invention and Muslim scholars define it as either a guarantee given by the issuer to the seller who accepts it or as a transfer of the debt by the debtor to another party, the issuer [13]. Hence, it falls within the permissible transactions. However, there are 
two problems, one for the issuer and the other for the user. This relates to the fact that the contract here usually contains an interest if payment is delayed and if cash is withdrawn. The Holly Qur' an prohibited Riba, and also the Prophet (SAW) also prohibited unjust transaction but there is no prohibition on transactions that involve third party.

Issuing of credit card in Islam: There is no doubt that issuing interest-based credit card is not permitted by any Islamic bank or financial institutions. Islamic banks issue credit cards that are not interest based. Banks do not really benefit from the credit card itself, and they provide it as a service to their customers.

Accepting of credit card in Islam: No Muslim is permitted of issuing of interest-based credit card but accepting it is permissible because they give a choice to the user of either going on interest-based or settling within the grace period without any interest. The user will be able to purchase only and settle within the grace period and not withdraw cash because cash withdrawal generates interest.

\section{Payment by using SMS}

Unlike debit or credit card payment, SMS is convenient in the developing countries where mobile phone is more available than debit or credit cards. As mentioned earlier the 3 simple steps to complete the transaction through SMS are as follows:

Firstly customer sends SMS from cell phone to his bank's specific dedicated cell number by informing his ID, password, seller account, deposit amount and other necessary information.

Secondly cell phone at customer's bank receives SMS and verifies authentication and it passes some arguments including seller's account ID, amount to be paid, etc using Internet.

Thirdly on the basis of validity of seller's accounts seller's bank updates sellers account and confirm the seller about the same.

According to the Hadith of Prophet Muhammad (SAW): "It is unlawful for Muslims to take over other Muslim's property without their consent." Our proposed m-payment model through SMS overcomes the problem of using third party and the overall operation of the system is very much simple and easy to implement. Since the money is transferred almost immediately from consumer's bank account to the merchant's account, there is no room for interest. There is no extra charge without very nominal SMS charge. So Mcommerce through SMS is Islamic because it is not generating any 
interest which is haram in Islam. Besides that it is establishing justice, security and well being of both parties.

\section{Islamic Rules for M-commerce}

When people wish to do business through mobile, they should ask for information about the products, company's background, ingredients of the products, etc. Muslims should have a clear picture of the products and ensure that the transaction is permissible under Islam. In order to form a valid contract, Islamic law says that the contract should be based on mutual consent. In Hadith, Prophet Muhammad (SAW) says: "verily, the sale should be based on mutual consent."

According to Ustaz Mustafa Omar[15], there are five conditions or steps in the process of purchasing goods through M-Commerce, which Islam states as a guideline in order to ensure the validity of the M-Commerce

1. Initiating the contract (al-ta'kud): This is the beginning stage of initiating the contract for both parties (buyers and sellers). The channels of communication (mobile devices) must be capable to link to each other. Buyers have to check the existence of the company and status of the company. It is important to make sure all elements are present: offer (Ijab), acceptance (Qabul), subject matter (Mahallul 'Aqd), and mode of expression (Sighah). "O ye who believe! Fulfill your obligation" [5:1].

2. Verification of the contract (sihha): This is to specify whether the transaction is permissible and whether it can be delivered or not. The contract must be free from Riba' (usury), which is prohibited in Islamic law especially when people pay through credit card.

3. Implementation (nafath): At this stage, two things must be confirmed. First, to ensure the person who offers the product is the real owner and has absolute rights and authority over the product. Second, the product is free to sell from Islamic perspective.

4. Binding (ilzham): No body should pull out; if a new product is not familiar. The seller is bound to convince the buyer.

5. Completion (tamam): This is the final stage when the seller and buyer exchange goods and prices.

\section{Conclusion}

The prospect of SMS has already been accepted by most of the mobile service providers and also by the retailers. In case of commercial 
institutions it is seen the case of Standard Chartered who has already taken steps to provide services to their customers through SMS. In this paper a guideline of $\mathrm{M}$-Commerce applications has been proposed for developing countries where mobile phone facilities are more available in compare to other electronic payment facilities. Muslims should have a clear conception that the transaction is permissible under Islam. The MCommerce setup is likely to be changed due to our socio-economic infrastructure and the technology-based environment. Payment through SMS system is not creating any interest; it is establishing justice, security and well being of both parties. So Islamic Shariah also accepts it.

\section{REFERENCES}

1. A.Azim, A.F.M.S. kabir, M.F.Zibran, (2005) "Alternative Frameworks of E-commerce and Electronic Payment Systems Specially Suitable for the Developing Countries like Bangladesh", ICCIT2005

2. Mobile payments in m-commerce, Telecom Media Networks

3. P. Kotler, D.C. Jain and S. Maesincee, (2002) Marketing Moves, Harvard Business School Press, Boston.

4. S. Balasubramanian, R.A. Peterson and S.L. Jarvenpaa,(2002) Exploring the implications of M-Commerce for markets and marketing, Journal of the Academy of Marketing Science 30 (4), pp. 348-361.

5. P.M. Doney and J.P. Cannon, (1997) An examination of the nature of trust in buyer-seller relationships. Journal of Marketing 52, pp. 21-34.

6. Available at: http://www.celent.com / PressReleases / 20060213 / Mobile Commerce .htm

7. Available at: http://www.bharatbook.com/detail.asp?id=30023

8. GrammenPhone. www.grammenphone.com

9. M. M.Ashraf, S.Haque, "Short messaging service as a Business to Customer Marketing Tool: A Proposed model in context of Bangladesh", IICIT2005

10. Abu-Sulayman Abdul Hamid Ahmad,(1980) The Theory of the Economics of Islam, Contemporary Aspects of Economic Thinking in Islam, International Graphics Printing Service, Maryland, pp34

11. Afzal-Ur-Rahman,(1980) Economic Doctrines of Islam, vol.1, Islamic Publications Ltd. Pakistan. Pp.66

12. Available at: http://www.islam-online.net / fatwa / english / fatwadisplay.asp? hfatwaid $=70939$

13. Yousuf Ali, The Holy Qur'an - English Translation,

14. The new edition of the report, 'Mobile Messaging Futures 2010-2014', http://www.mobile88.com/news/read.asp?file=/2010/2/3/20100202215754 $\& \mathrm{sec}=$ International\&phone $=$ SMS

15. Mobile Commerce from an Islamic Perspective http://www.cit.griffith.edu.au/conferences/qualit2004/otherpapers.d/qualit20 04paper59.doc 